Volume 21 Number 1 June 2021. P. 205-221

https://doi.org/10.30603/au.v21i1.2112

\title{
Transmigration Village and Construction of Religious Harmony: Evidences From Mamasa of West Sulawesi
}

\author{
Muhammad Arsyam1, Zakirah², Sulaiman Ibrahim³ \\ 1STAI DDI Kota Makassar,2,3 Institut Agama Islam Negeri Sultan Amai Gorontalo
}

\begin{abstract}
The focus of this research is finding the construction of religious harmony in former conflict areas in Indonesia. The aim is to photograph the process of resolving religious conflicts in Kampung Rano in Mamasa of West Sulawesi Province. This research uses a qualitative method using a phenomenological approach by collecting socio-religious data and interviews from researchers with objects. This study empirically shows that finds the importance of understanding the value of pluralism has been taking place, especially for the people of Kampung Rano to regenerate an economic situation that has been devastated for more than a decade. On the other hand, there are a number of agreements between the transmigrant community and local residents, one of which is to no longer use religious attributes and symbols in political activities.
\end{abstract}

Keywords: Transmigration, Construction of Diverse Harmony

\section{Kampung Transmigrasi dan Kontruksi Kerukunan Umat Beragama; Mamasa Sebagai Wilayah Pasca Konflik}

\begin{abstract}
Abstrak
Fokus penelitian ini menemukan kontruksi kerukunan umat beragama di bekas wilayah konflik di Indonesia. Tujuannya adalah memotret proses penyelesaian konflik beragama di Kampung Rano di Mamasa, Province Sulawesi Barat. Penelitan ini melalui metode kualitatif menggunakan pendekatan fenomenologi dengan menghimpun data sosial-agama dan wawancara dari peneliti dengan objek. Penelitian ini menemukan pentingnya memahami nilai kemajemukan, terutama untuk masyarakat Kampung Rano agar dapat menumbuhkan kembali situasi ekonomi yang porak-poranda selama lebih dari satu dekade. Di sisi lain terdapat sejumlah kesepakatan antara masyarakat transmigran dan penduduk lokal, salah satunya untuk tidak lagi menggunakan atribut dan simbol agama dalam aktivitas politik.
\end{abstract}

Kata Kunci: Transmigrasi, Konstruksikerukunan umat beragama, mamasa, pasca konflik

Author correspondence

Email: arsyam0505@gmail.com

Available online at http://journal.iaingorontalo.ac.id/index.php/au/index 


\section{A. Introduction}

Horizontal conflicts between religions on the mainland of Sulawesi have not occurred once. Call it the Poso conflict, a conflict with a religious background that broke out in 1998 and spread to several areas on the island of Sulawesi until 2007, claimed hundreds of lives, and created a tense atmosphere in several surrounding areas. In order to legitimize the conflict, religious symbols are scattered to serve as fuel for conflict, even though the source of the conflict is not as simple as a religious conflict. ${ }^{1}$ Unfortunately, it surfaced in several cases of horizontal conflict, the presence of differences was the trigger for the spread of conflict. This is because a black-and-white dichotomy exists between one identity and the other between the two warring camps. Various motivations can trigger acts of mass destruction to destroy property until the opponent's life is merciless, such as revenge, weakening the opponent before finally attacking back, confusing information, differences in ethnicity, language, religious origins, and others. The widespread issue of conflict in the name of religion in Sulawesi has a significant impact on harmony among human beings. According to Gerry van Kliken, the Poso conflict that occurred was driven more by increasing issues through the diffusion of information and dissemination between communities that were previously not socially related. ${ }^{2}$

Dissemination of information with nuances of ethnic, religious, racial, and inter-group (Suku Agama, Ras, dan Antar Golongan - SARA) issues in Poso, Central Sulawesi, continues to grow to the surrounding areas, even triggering racial conflicts outside the province, especially in areas with plural societies or communities, various beliefs, and local customs. North Luwu Regency, South Sulawesi Province, is one of the impacts. SARA-based conflict erupted in 2000. Although the scale of the conflict was not as large as Poso, North Luwu took two years to restore its citizens' economic situation and sense of security. Meanwhile, in West Sulawesi Province, Mamasa Regency felt the most impact. The situation is

\footnotetext{
1 Zuldin, M. (2019). Ketimpangan Sebagai Penyebab Konflik: Kajian atas Teori Sosial Kontemporer. TEMALI: Jurnal Pembangunan Sosial, 2(1), 157-183.

2 Yakobus, I. K., Yahya, M., \& Agustang, A. D. M. P. (2019). Revitalisasi Nilai Budaya Sintuwu Maroso Sebagai Alternative Resolusi Pasca Konflik di Kabupaten Poso. Jurnal Sosio Sains, 5(1), 14-21.
} 
tense in remote villages. The climax was the conflict in 2004. Prolonged tensions caused residents to feel insecure, so many of them chose to leave the village.

Mamasa Regency is one of the areas with the dominance of the Mandar and Toraja ethnic groups. ${ }^{3}$ This area was once rumored to be one of the locations of the worst conflict, which was the spillover of the Poso conflict. One of the red zones of socio-religious conflict in Mamasa is Kampung Rano. Rano Village is located in Mehalaan Village, Mehalaan District, Mamasa Regency, West Sulawesi Province. According to Tempo.co, the conflict in Kampung Rano stems from a dispute over local political attitudes in 2004, which led to a clash between residents who rented out three people and burned dozens of houses. This dispute permeated into a religious identity feud. Even though they are wrapped in ethnicity, language, blood (still related to family), and culture, this horizontal conflict is inevitable by religious differences. Apart from the issues mentioned above, the presence of conflict in Rano Village caused at least ten casualties, dozens of houses were burned, hundreds of rice fields were abandoned, and tens of hundreds of families were displaced.

At first, the village of Rano was inhabited by several family groups from the Mandar, Toraja, and Mamasa ethnic. Initially, Rano village was in the administrative area of Mambi District. The conflict over the ATM (stands for Aralle, Tabuhanan, and Mambi) that occurred in 2003 was triggered by the issuance of Law No. 11 of 2002 concerning regional expansion, namely Mamasa from Polmas Regency and Palopo from Luwu Regency. While the people of Palopo welcomed the new policy, Mamasa's condition suddenly became tense. This is due to historical and customary issues. The people of Aralle, Tabuhan, and Mambi sub-districts want to remain with Polmas because of the transfer of the district capital to Mamasa. People will lead the people of Mandar Islam descent from the Mamasa tribe who are not from the Mandar tribe. The first conflict was in 2003, the second was in 2004, and the last was in 2005. Kampung Rano, inhabited by families from the Mandar, Mamasa, and Toraja tribes, after trying not to get involved in external

\footnotetext{
3Bahri, S. (2019, September). Mengurai Peristiwa 1998, Konflik Antar Kelompok Penghuni Perumnas Btp Makassar (Figthing Intergroup at Bumi Tamalanrea Permai (Btp) Housing Makassar). In Seminar Series in Humanities and Social Sciences (No. 1).
} 
conflicts, finally erupted in September 2004. Since the emergence of the conflict, this village has become a dead land no longer inhabited by residents. The conflict in Rano village made all residents choose to evacuate and leave abandoned agricultural lands. ${ }^{4}$ The impact of this conflict is that many teachers leave schools. Many of them are supporters of regional expansion. On the other hand, religious activity is slowly starting to rise, although it is still a little lame. Until 2008 the Christian worship activities were still not going well. This is evidenced by the absence of activity at the Mamasa Toraja Church. The congregation and the pastor still choose to live in refugee camps rather than return to their homes.

Socio-cultural development efforts in Rano Village continued to be built until the local government of the Mamasa Regency and the community. Local traditional leaders recommended the Rano village area to become the Transmigration Settlement Unit (Unit Permukiman Transmigrasi - UPT) in 2016. efforts to form an independent village and feasible to develop. ${ }^{5}$ Apart from the development of the UPT, there are values to be built in this area by carrying out engineering to re-embrace the values and order of safe social life in an atmosphere of the life of diverse religious beliefs. This effort aligns with the transmigration development mission, which is to build a shared socio-cultural atmosphere for regional economic development.

The development of the Rano village through the regional transmigration program was carried out by bringing in groups of residents from outside the district. The original population transmigration (Transmigrasi Penduduk Asal TPA) who inhabit the area from Java is $30 \%$ of families. The purpose of holding the community of origin or immigrants is to establish cooperation between regions and transfer knowledge and experience in carrying out economic activities, especially in the agricultural sector. ${ }^{6}$ This condition will get better if the values of togetherness and social relations are well developed to achieve development

\footnotetext{
${ }^{4}$ Rosdiana, (2008) Implementasi Pendidikan Agama dan Keagamaan Pasca Konflik di Daerah Mambi Sulawesi Barat. Jurnal Al-qalam, No.22.

5 Abdullah, S., Sultan, S., \& Matande, R. S. (2018). Makna kearifan lokal To Parenge dalam penyelesaian konflik lahan di Tana Toraja. Jurnal Sosiologi Dialektika, 13(2), 122-131.

${ }^{6}$ Malau, M. T. (2014). Aspek hukum peraturan dan kebijakan pemerintah Indonesia menghadapi liberalisasi ekonomi regional: Masyarakat ekonomi ASEAN 2015. Jurnal Rechts Vinding: Media Pembinaan Hukum Nasional, 3(2), 163-182.
} 
goals. ${ }^{7}$ However, it will become a new social problem if there are interactions that do not go well in this region, considering the characteristics of different cultures and religions.

Regarding the conditions mentioned above, a study on the resolution of the conflict resolution of the Rano village and its current condition after being made a transmigration village was carried out. This study is critical to minimize the possibility of conflicts that could potentially occur in the Mamasa Regency area in the future, especially in the UPT.

Rano Village has now returned to be a community group that is part of Mehalaan Village, Mehalaan District, Mamasa Regency. So, departing from the background mentioned above, this study seeks to formulate how to resolve religious conflicts in Rano village before and after being made a Transmigration Settlement Unit. With this description, a mapping of the settlement of disputes between these groups can be made concretely between before the existence of the Transmigration Settlement Unit and after the program's existence.

\section{B. Theoretical Framework}

\section{Conflict}

Conflict, by Coser, is "a struggle over values and claims to protect status, power, and resources, a struggle in which the main objective of the opponent is to neutralize, injure, or eliminate the competitor." 8 In his view, the functions of social conflicts that occur in society include 9 :

a) Conflict can be a solution to a chaotic situation. This causes the safety valve (klep) to function as a solution in reducing disputes;

b) The possible accumulation of aggressive anger in realistic conflict (derived from disappointment) and unrealistic conflict

\footnotetext{
7Yunus, R. (2013). Transformasi nilai-nilai budaya lokal sebagai upaya pembangunan karakter bangsa. Jurnal Penelitian Pendidikan, 13(1), 67-79.

${ }^{8}$ Muqoyyidin, A. W. (2013). Potret konflik bernuansa agama di Indonesia (signifikansi model resolusi berbasis teologi transformatif). ANALISIS: Jurnal Studi Keislaman, 12(2), 319-344.

${ }^{9}$ Sipayung, M. E. (2016). Konflik Sosial dalam Novel Maryam karya Okky Madasari: Kajian Sosiologi Sastra. Sintesis, 10(1), 22-34.
} 
stemming from efforts to defuse tension initiate disputes before the conflict situation is abated;

c) Hostility is not necessarily the end of a conflict;

d) By conflict, the strength and stability of the relationship can be tested.

e) Conflicts with various out-groups can strengthen the internal cohesion of a group.

If viewed from (human nature), in essence, conflict always offers harmony and justice in every living and living space. ${ }^{10}$ Therefore, according to Burton, conflict is not human nature. ${ }^{11}$ Conflict is triggered by the socio-economic structure surrounding life, especially when basic human needs are not met. The level of justice in a social order that is not equal and balanced between individuals often creates friction of interests that impact disharmony in the form of conflict. ${ }^{12}$ This factor is considered that the existence of conflict is part of the process of social change born from the heterogeneity of interests and values of belief.

Another definition of conflict, expressed by Rubin, is the continuous neglect of the aspirations of a community group, resulting in the polarization of various interests or beliefs. ${ }^{13}$ Changes in dynamic political conditions make the age of conflict in line with the system of human civilization. Increasing the quality of the degree of conflict of a group, the smaller the degree of integration. ${ }^{14}$ The definition of integration is assessed from the solidarity between groups in carrying out the principles of life they adhere to.

\footnotetext{
${ }^{10}$ Nursyamsi, N. (2015). Pandangan Konselor Terhadap Konseli Dalam Proses Bimbingan Dan Konseling (Kajian Filosofis Hakikat Manusia Berdasarkan Alquran).Jurnal Al-Taujih: Bingkai Bimbingan dan Konseling Islami, 1(1), 1-28.

${ }^{11}$ Hayat, H. (2013). Teori Konflik Dalam Persfektif Hukum Islam: Interkoneksi Islam Dan Sosial. HUNAFA: Jurnal Studia Islamika, 10 (2), 269-292.

12Sagama, S. (2016). Analisis Konsep Keadilan, Kepastian Hukum dan Kemanfaatan dalam Pengelolaan Lingkungan. Mazahib, 15(1), 20-41.

${ }^{13}$ Scott, B. N., Carcello, J. V., Hollingsworth, C. W., \& Neal, T. L. (2012). Barnea, A. \& Rubin, A. (2010). Corporate Social Responsibility as a Conflict Between Shareholders. Journal of Business Ethics, 97 (1). Benson Wier. 2012." Is Earnings Quality Associated with Corporate Social Responsibility?". The Accounting Review, 87 (3): 761-796. Jurnal Administrasi Bisnis (JAB), 41, 1.

${ }^{14} U$ tami, H. N. (2007). Analisis Jaringan Komunikasi Untuk Menunjang Kegiatan Pemasaran Pada Industri Kecil (Communication Network Analysis to Support Small Industry Marketing). Iqtishoduna, 2(1).
} 
Humans view conflict as a positive and negative social fact. Conflict is seen as positive when it does not cause disintegration. In addition, conflict is seen as positive because it can correct norms that are not working well. Even though it takes a social cost, it is undeniable that conflict can also encourage social change. On the other hand, conflict becomes detrimental when it has disintegrative implications. Most people interpret conflict as a negative social phenomenon. This is understandable because conflicts have led to more disintegrative actions than integrative ones so far. ${ }^{15}$

At the current level, the conflict that is a hotly discussed state issue is blasphemy. This term makes groups impose their religion to defend their beliefs with opposing goals. The concept of blasphemy should be placed in a consistent system of rules by all religions, both Islam and other religions, to avoid patterns of conflict between people. ${ }^{16}$ Therefore, the rules of religious belief can provide tolerance for others without having problems with each other without creating a situation of blaspheming religion, anti-tolerance, and radicalism. ${ }^{17}$

\section{Religion and Social Conflict}

In religious life, there are frictions or disputes between religious communities due to various reasons, which are caused by religious doctrine and external factors such as economic, social, and political. The occurrence of religious conflicts resulted in significant losses to economic development and psychological trauma for the people involved in it. ${ }^{18}$ The cases of religious conflicts that have occurred cause damage to the relationship between the two adherents of the faith. However, in some of the existing conflicts, rebuilding space to introspect the differences of each believer. Not a few groups that experience conflict have succeeded in building an everyday life and improving as a community's religious community.

\footnotetext{
${ }^{15}$ Asroni, A. (2020). Resolusi Konflik Agama: Perspektif Filsafat Perenial. Religi: Jurnal Studi Agamaagama, 16(1), 64-78

16Jati, W. R. (2013). Kearifan lokal sebagai resolusi konflik keagamaan. Walisongo: Jurnal Penelitian Sosial Keagamaan, 21(2), 393-416.

${ }^{17 H a f i d z i, ~ A . ~(2019) . ~ K o n s e p ~ T o l e r a n s i ~ D a n ~ K e m a t a n g a n ~ A g a m a ~ D a l a m ~ K o n f l i k ~ B e r a g a m a ~ D i ~}$ Masyarakat Indonesia. Potret Pemikiran, 23(2), 51-61.

${ }^{18}$ Alganih, I. (2016). Konflik Poso (Kajian Historis Tahun 1998-2001). Criksetra: Jurnal Pendidikan Sejarah, 5(2).
} 
Resolving religious conflicts is not an easy thing. Call it the Aceh conflict, the Ambon conflict, the Poso conflict, and other conflict incidents in Indonesia that are still guarded by the community and the government. Conflict resolution requires awareness and social cooperation to end the conflict. ${ }^{19}$ Moreover, the conflicts that occur often raise and act in the name of religion, even though one of the vital elements as an adhesive for social and cultural integration in society is religion, as the people of West Papua with diversity that remains harmonious and unaffected even though geographically close to Ambon when the Ambon conflict occurred which raises religious issues. ${ }^{20}$ Usman explains that the social integration that occurs is not in line with the existence of conflict. With the existence of conflict, the balance of relations can be reorganized and re-created. This gives an understanding that integration is born from continuous and intensive social interaction and communication.

Conflict in the name of religion affects social life, which is known as social conflict. ${ }^{21}$ Social problems are influenced by, first, differences in individual points of view, attitudes, and attitudes, and feelings that have the potential to create friction and conflict. Second, cultural differences are caused by the physical environment and socio-cultural environment that form social patterns. Community groups become the background for the formation of differences. Third, there are differences in tendencies that include political, economic, and other interests, and fourth, social change.

According to Jonson (1994), socio-religious conflicts can be resolved by taking several actions, namely; (1) the basics of conflict are removed from those who act in conflict involvement 2) the existence of a winning group and a losing group 3) negotiation, 4) peace, and 5) peace which is considered impossible. So with that, even though social phenomena can create a conflict, it does not mean that conflict must occur for a long time. The final resolution of a conflict can be

\footnotetext{
${ }^{19}$ Nurfalah, Y. (2019). Pendidikan Damai Alternatif Pendidikan Korban Konflik Komunitas Syi'ah Sampang Madura. Tribakti: Jurnal Pemikiran Keislaman, 30(1), 85-114

${ }^{20}$ Wekke, I. S. (2016). Harmoni Sosial Dalam Keberagaman Dan Keberagamaan Masyarakat Minoritas Muslim Papua Barat. Kalam, 10(2), 295-312

21Pettalongi, S. S. (2013). Islam dan Pendidikan Humanis dalam resolusi konflik sosial. Cakrawala Pendidikan, (2), 95142.
} 
Transmigration Village and Construction of Religious Harmony: Evidences From Mamasa of West Sulawesi

because of being tired or bored or the desire to replace his energy with something new. ${ }^{22}$

\section{Religion and Social Integration}

Integration is defined as unification or merging, which has the meaning of efforts in constructing relative independence of the parts of living organisms or members of society. This is expected to create conditions and harmonious relationships to create an atmosphere of cooperation to achieve the goals that have been determined together. ${ }^{23}$ The realization of social integration is a situation when specialized parts can depend on each other. In other words, solidarity arises in a heterogeneous society based on functional values and beliefs. Social integration can be divided into two parts, namely: first, normative integration in a cultural perspective, by encouraging mechanical solidarity that is formed through trust and fostering values in achieving success in society; second, functional integration that tends to organic solidarity, namely the formation of solidarity between elements in society through relationships and a sense of interdependence between one another, both between sections and sections and society. ${ }^{24}$

In line with that, according to Nazmuddin, five principles are the basis for building social integration in society: (1) All religions teach goodness, not evil or evil; (2) there are similarities in several teachings in every religion such as advocating doing good to others; (3) There are fundamental differences in the teachings of religions. Among them, differences in scriptures, prophets, and ordinances of worship; (4) There is evidence of religious truth; (5) not forcing other people to embrace a particular religion. ${ }^{25}$

Society, as explained by Karsidi (1998), can achieve integration with several conditions. First, integration can occur if every member of the community feels

\footnotetext{
${ }^{22}$ Syamsuddin, A. (2020). Konflik Sosial dalam Perspektif Sosiologi Agama. Al-Din: Jurnal Dakwah dan Sosial Keagamaan, 6(1).

${ }^{23}$ Syafrizal, S. (2021). The urgency of Government Regulation of Law As An Effective Solution To Eradicate Corruption. Indonesian Journal of Law and Policy Studies, 2(1), 1-11.

${ }^{24}$ Wirawan, D. I. (2012). Teori-teori Sosial dalam Tiga Paradigma: fakta sosial, definisi sosial, dan perilaku sosial. Kencana.

${ }^{25}$ Wirawan, D. I. (2012). Teori-teori Sosial dalam Tiga Paradigma: fakta sosial, definisi sosial, dan

perilaku sosial. Kencana.
} 
that they are not harmed. Even the benefits can be more significant; Second, there is an adjustment in understanding norms. In this case, adjusting behavior in society should be under the values and challenges faced; Third, a clear functional structure can be formed if the prevailing norms move consistently. It is also explained here that social integration can run optimally through three steps-first, accommodation. Here, the two conflicting parties seek solutions to problems, reconcile contradictions and differences, and resolve problems through coordination. Second, coordination is the embodiment of a form of cooperation. Third, assimilation is a marriage or mixing of two good cultures through cultural contact by assimilation and acculturation. These stages can start a more harmonious relationship-building to create interdependent relationships between each other so that each party is aware of their respective roles. In this stage, the terms in the group (us) and out-group (them) are no longer known because both have an essential role in building the expected life.

This study was built by referring to data in three-time phases: a socioreligious conflict, the construction of a transmigration village, and the current time phase. This study examines whether socio-religious issues cause conflict in Rano village and whether the transmigration village development policy is a resolution in resolving conflicts in the Rano village area, Mamasa Regency. The evaluation of the assessment and analysis parameters is carried out by collecting some data and facts in the field related to the fundamental problems of conflict and the indicators possessed in transmigration development policies through transmigration villages or transmigration settlement units. In detail, this research study is compiled by the theoretical framework below. Conflict resolution in Rano village was completed with an instrument built by the local government through the transmigration program with various parameters of achievement.

Based on the theoretical framework above, this study summarizes some hypotheses; namely, the social, religious conflict in 2004 did not originate from religious issues. This can be seen from residents who live to live a socio-economic life by carrying out the norms and family values adopted by the family even though in one clump, there are adherents of different religions. 

of West Sulawesi

\section{Research Method}

The research was conducted from March to May 2021. The research location is Rano Village, Mehalaan Village, Mehalaan District, Mamasa Regency, West Sulawesi Province. The research was conducted starting with the administrative process of licensing from the Darud Dakwah Wal Irsyad Islamic School (STAI-DDI) campus of Makassar City, which was addressed to the local government of Mamasa Regency. In carrying out the administration, the process of further communication is carried out with various parties who may be involved in this research. This permit includes the willingness of assistance by the local government and the security forces to assist the continuity of the research.

This research is qualitative research using a phenomenological approach. This approach builds the construction of reality by searching for social data on religion and reality by interacting with interviews from researchers with objects, namely respondents, regarding conflicts in Rano village. The results of interviews with respondents will be processed by descriptive analysis. ${ }^{26}$

Data obtained from respondents through in-depth interviews conducted directly. The target locus of respondents is the village government, the head of the Rano Transmigration Settlement Unit, the local government (public relations and the department of religion), transmigration residents (TPA and TPS), the transmigration office, and religious figures who are considered and trusted to know the chronology of the conflicts that occurred in Rano village. Data collection is done by giving questions to respondents. Data collection uses notes, documentation, and recorded statements from respondents.

\section{The solution to the religious conflict in Rano village before it was made the Transmigration Settlement Unit.}

Government support for the transmigration program is contained in Presidential Decree no. 50 of 2018 concerning the coordination and integration of the implementation of transmigration. From this reference, it is explained that the government is severe in handling the transmigration program, which significantly

\footnotetext{
${ }^{26}$ Irawan, F., \& Muarifah, E. (2020). Analisis Penerapan Corporate Social Responsibilty in the Sharia Enterprise Theory. Minhaj: Jurnal Ilmu Syariah, 1(2), 149-178.
} 
contributes to creating a new center of economic growth, building socio-cultural, and increasing regional income.

Transmigration has a noble purpose and is the basis for regional development. The motto built through the program is "Real Work Transmigration to Build the Nation." Regional Development in the West Sulawesi Province provides clear evidence of positive economic acceleration since 2002. Mamasa Regency became an autonomous region and continues to strive to make the region independent and competitive with the surrounding regions. The real work of the region through transmigration is evidenced by the formation of the Botten Passembuk Settlement Unit in Mehalaan District, Mamasa Regency, in 2011. This development continues and has become the definitive village led by a definitive village head. ${ }^{27}$

Significant economic development and growth in the Mamasa Regency area through the transmigration program made the Central Government (Ministry of Villages, Development of Disadvantaged Regions and Transmigration) continue to provide opportunities for this region so that in 2016, the Rano Settlement Unit (Satuan Permukiman - SP 2) began built with the pattern of dryland agricultural transmigration for businesses. Kampung Rano is appointed and recommended by the local village government as a transmigration settlement area. The residents who will inhabit are local people who own land in that location plus vacant land designated by the government as transmigrant settlement land. The efforts made by the village government and several communities and religious leaders had a positive impact. Namely, in 2016 the Rano Settlement Unit began to be built and carried out in stages. ${ }^{28}$

In 2020, the location of Rano village in the Transmigration Settlement Unit had been inhabited by 215 families (Mamasa Regency Transmigration Office, 2020). In the course of its development, the people living in this area began to rebuild social harmony that is with each other and immigrant communities from

${ }^{27}$ ALBAR, M. R. Wawancara Tentang Tata kelola pembangunan transmigrasi.

${ }^{28}$ Amir, M., \& Rahman, R. Wonomulyo. Wawancara Tentang Kolonisasi ke Transmigrasi 1937-1952. 
the island of Java. This condition is the big key that the socio-religious conflicts in this region can be built with a transmigration policy approach.

\section{E. Efforts to resolve social conflicts, pluralism, and religious harmony in Rano village after being made a Transmigration Settlement Unit.}

Before the establishment of UPT Kampung Rano, conflict resolution certainly had a significant difference with the settlement after the presence of transmigrants in the village. Of course, the existence of new residents has social institutions that must change or may be abolished. The process towards improvement is carried out more carefully because large numbers of transmigrants will easily cause new social conflicts. Therefore, handling conflicts or, in this case, efforts to reduce anxiety, trauma and restore a sense of security for residents is the main thing.

Conciliation is a method used by interacting with institutions, in this case. These institutions actively interact with or become parts of the community, such as religious institutions, education, religious education, other government institutions, and other traditional community groups. Conciliation efforts are seen as quite effective in conflict control to foster the possibility of forming a pattern of discussion and decision-making between the parties involved in the conflict on the disputed issue in a peaceful manner and approach.

The next step is to meditate. Suppose conflict control through conciliation does not find a bright spot. In that case, a mediation method or approach is needed to reconcile the parties involved in the conflict. A third party appointed to advise both parties to stop the conflict and resolve the conflict between them. Even in this case, the status of the third party is not binding, and the input or advice may or may not be carried out by those involved in the conflict. Therefore, it is necessary to realize this social welfare and motivate as mentioned above, accompanied by instructions on how to make it happen. ${ }^{29}$

Control through arbitration. This move is considered the worst decision of the two sides' peace efforts. Because if a solution has not been found and is still

29 Arsyam, M., \& Alwi, A. M. (2020). Konsep dan Makna Kesejahteraan dalam Pandangan Islam. https://osf.io/u45gn/download?format=pdf. h. 2 
ongoing, conflict is needed to be controlled through arbitration. The referee is not present to justify the need for a dispute but the intervention of a third party to control the anger of both parties by making conflicting regulations that have legal consequences by both parties in the event of a violation in the conflict. With the intention that the two conflicting parties agree or are forced to accept decisions issued by third parties to control the conflicts that occur, the parties involved can decide from the referee or third parties. ${ }^{30}$

It can also be explained that local government instruments can resolve or reduce conflicts through the policy of developing the UPT Rano. The motivation for the development is based on the socio-cultural conditions that exist between residents and residents who leave the area back to become transmigrants and become local transmigration fostered residents. Before becoming a transmigration target in Rano village, the local government made an integrity pact and an agreement not to conflict in social religion so that migrants can collaborate in economic activities with residents in Rano village.

From the results of an empirical study in the village, there has been a significant economic increase through the empowerment of abandoned land into productive land. With the increase in the economy, social interaction with others between TPS and TPA can create a conducive atmosphere, avoid social-religious conflicts that have occurred before, and agreements have been made through local politics with several elements of society, so that old conflicts are no longer a reason for overwhelmingly divorce.

\section{F. Conclusion}

The destruction of the community structure in Rano Village after the bloody conflict in 2004 due to political events that turned into ethnic and religious conflicts took a very long time to recover. Evidently, through the transmigration program, the government turned out to be able to restore significant economic growth in the Mamasa Regency area by starting to build with the dry land

\footnotetext{
${ }^{30}$ Retnowati, P. (2018). Agama, Konflik dan Integrasi Sosial Refleksi Kehidupan Beragama di Indonesia: Belajar dari Komunitas Situbondo Membangun Integrasi Pasca Konflik. SANGKéP: Jurnal Kajian Sosial Keagamaan, 1(1), 1-28.
} 
agricultural transmigration business pattern in Rano Village. This condition proves and at the same time becomes one of the primary keys to conflict resolution in Rano Village, that socio-religious conflicts that occur in the area can be built by means or a structural approach without using a repressive agenda, namely the transmigration policy through the government.

The local government has also agreed, in this case, an integrity pact and an agreement not to contest in any case on behalf of ethnicity, religion, and class so that migrants can also collaborate socially in economic activities with residents in Rano village. Other efforts that have been made are Conciliation, Mediation, and Control through arbitration.

\section{REFERENCES}

Abdullah, A. (2016). Gerakan Radikalisme dalam Islam: Perspektif Historis. Addin, 10(1), 1-28.

Abdullah, S., Sultan, S., \& Matande, R. S. (2018). Makna kearifan lokal To Parenge dalam penyelesaian konflik lahan di Tana Toraja.Jurnal Sosiologi Dialektika, 13(2), 122-131.

ALBAR, M. R. TATA KELOLA PEMBANGUNAN TRANSMIGRASI.

Alganih, I. (2016). Konflik Poso (Kajian Historis Tahun 1998-2001). Criksetra: Jurnal Pendidikan Sejarah, 5(2).

Amir, M., \& Rahman, R. Wonomulyo: dari Kolonisasi ke Transmigrasi 1937-1952.

Araiyyah, Hamdan (2018). MENUJU DAMAI MENUJU DAMAI DENGAN KEARIFAN BARU (Studi Kasus Pasca Konflik Di Aralle, Tabulahan, dan Mambi). Moraref: Balai Penelitian dan Pengembangan Agama Makassar, 11(2). DOI: 10.31969/alq.v11i2.588

Arsyam, M., \& Alwi, A. M. (2020). Konsep dan Makna Kesejahteraan dalam Pandangan Islam. https://osf.io/u45gn/download?format=pdf.

Asroni, A. (2020). Resolusi Konflik Agama: Perspektif Filsafat Perenial. Religi: Jurnal Studi Agama-agama, 16(1), 64-78.

Bahri, S. (2019, September). MENGURAI PERISTIWA 1998, KONFLIK ANTAR KELOMPOK PENGHUNI PERUMNAS BTP MAKASSAR (FIGTHING INTERGROUP AT BUMI TAMALANREA PERMAI (BTP) HOUSING MAKASSAR). In Seminar Series in Humanities and Social Sciences (No. 1).

Dewantara, A. W. (2015). Pancasila Sebagai Pondasi Pendidikan Agama Di Indonesia. CIVIS, 5(1/Januari). 
Hafidzi, A. (2019). Konsep Toleransi Dan Kematangan Agama Dalam Konflik Beragama Di Masyarakat Indonesia. Potret Pemikiran, 23(2), 51-61.

Hayat, H. (2013). TEORI KONFLIK DALAM PERSFEKTIF HUKUM ISLAM: INTERKONEKSI ISLAM DAN SOSIAL. HUNAFA: Jurnal Studia Islamika, 10(2), 269-292.

Irawan, F., \& Muarifah, E. (2020). ANALISIS PENERAPAN CORPORATE SOCIAL RESPONSIBILTY (CSR) DALAM PERSPEKTIF SHARIA ENTERPRISE THEORY: ANALISIS PENERAPAN CORPORATE SOCIAL RESPONSIBILTY (CSR) DALAM PERSPEKTIF SHARIA ENTERPRISE THEORY. Minhaj: Jurnal Ilmu Syariah, 1(2), 149-178.

Jati, W. R. (2013). Kearifan lokal sebagai resolusi konflik keagamaan. Walisongo: Jurnal Penelitian Sosial Keagamaan, 21(2), 393-416.

Lutfi, M. L. M. (2018). UPAYA MENINGKATKAN KOMUNIKASI ANTAR BUDAYA DENGAN TUJUAN HARMONISASI HEGEMONITAS WARGA. Network Media, 1(2).

Malau, M. T. (2014). Aspek hukum peraturan dan kebijakan pemerintah Indonesia menghadapi liberalisasi ekonomi regional: Masyarakat ekonomi ASEAN 2015. Jurnal Rechts Vinding: Media Pembinaan Hukum Nasional, 3(2), 163182.

Martiany, D. (2015). PEMBERDAYAAN PEREMPUAN DESA. Jurnal Aspirasi, 6(2), 203-212.

Muqoyyidin, A. W. (2013). Potret konflik bernuansa agama di Indonesia (signifikansi model resolusi berbasis teologi transformatif). ANALISIS: Jurnal Studi Keislaman, 12(2), 319-344.

Nurfalah, Y. (2019). Pendidikan Damai Alternatif Pendidikan Korban Konflik Komunitas Syi'ah Sampang Madura. Tribakti: Jurnal Pemikiran Keislaman, 30(1), 85-114.

Nursyamsi, N. (2015). PANDANGAN KONSELOR TERHADAP KONSELI DALAM PROSES BIMBINGAN DAN KONSELING (Kajian Filosofis Hakikat Manusia Berdasarkan Alquran). Jurnal Al-Taujih: Bingkai Bimbingan dan Konseling Islami, 1(1), 1-28.

Pettalongi, S. S. (2013). Islam dan Pendidikan Humanis dalam resolusi konflik sosial. Cakrawala Pendidikan, (2), 95142.

Retnowati, P. (2018). Agama, Konflik dan Integrasi Sosial Refleksi Kehidupan Beragama di Indonesia: Belajar dari Komunitas Situbondo Membangun Integrasi Pasca Konflik. SANGKéP: Jurnal Kajian Sosial Keagamaan, 1(1), 128.

Retnowati, R. (2014). Agama, Konflik, dan Integrasi Sosial (Integrasi Sosial Pasca Konflik, Situbondo). Analisa: Journal of Social Science and Religion,21(2), 189-200.

Rosdiana, (2008) Implementasi Pendidikan Agama dan Keagamaan Pasca Konflik di Daerah Mambi Sulawesi Barat. Jurnal Al-qalam, No.22 
Sagama, S. (2016). Analisis Konsep Keadilan, Kepastian Hukum dan Kemanfaatan dalam Pengelolaan Lingkungan. Mazahib, 15(1), 20-41.

Saihu, S. (2019). Pendidikan Pluralisme Agama: Kajian tentang Integrasi Budaya dan Agama dalam Menyelesaikan Konflik Sosial Kontemporer. Jurnal IndoIslamika, 9(1), 67-90.

Sari, D. C., Leuwol, N. V., Metanfanuan, T., Khalik, M. F., Saparuddin, S., Armus, R., ... \& Syafrizal, S. (2020). Sosiologi Agama. Yayasan Kita Menulis.

Scott, B. N., Carcello, J. V., Hollingsworth, C. W., \& Neal, T. L. (2012). Barnea, A. \& Rubin, A.(2010). Corporate Social Responsibility as a Conflict Between Shareholders. Journal of Business Ethics, 97 (1). Benson Wier. 2012." Is Earnings Quality Associated with Corporate Social Responsibility?". The Accounting Review, 87 (3): 761-796. Jurnal Administrasi Bisnis (JAB), 41, 1.

Sipayung, M. E. (2016). Konflik Sosial dalam Novel Maryam karya Okky Madasari: Kajian Sosiologi Sastra. Sintesis, 10(1), 22-34.

Syafrizal, S. (2021). URGENCY OF GOVERNMENT REGULATION OF LAW AS AN EFFECTIVE SOLUTION TO ERADICATE CORRUPTION. Indonesian Journal of Law and Policy Studies, 2(1), 1-11.

Syamsuddin, A. (2020). Konflik Sosial dalam Perspektif Sosiologi Agama. Al-Din: Jurnal Dakwah dan Sosial Keagamaan, 6(1).

Utami, H. N. (2007). ANALISIS JARINGAN KOMUNIKASI UNTUK MENUNJANG KEGIATAN PEMASARAN PADA INDUSTRI KECIL (COMMUNICATION NETWORK ANALYSIS TO SUPPORT SMALL INDUSTRY MARKETING). IQTISHODUNA, 2(1).

Wekke, I. S. (2016). Harmoni Sosial Dalam Keberagaman Dan Keberagamaan Masyarakat Minoritas Muslim Papua Barat. Kalam, 10(2), 295-312

Wirawan, D. I. (2012). Teori-teori Sosial dalam Tiga Paradigma: fakta sosial, definisi sosial, dan perilaku sosial. Kencana

Yakobus, I. K., Yahya, M., \& Agustang, A. D. M. P. (2019). Revitalisasi Nilai Budaya Sintuwu Maroso Sebagai Alternative Resolusi Pasca Konflik di Kabupaten Poso. Jurnal Sosio Sains, 5(1), 14-21.

Yunus, R. (2013). Transformasi nilai-nilai budaya lokal sebagai upaya pembangunan karakter bangsa. Jurnal Penelitian Pendidikan, 13(1), 67-79.

Zuldin, M. (2019). Ketimpangan Sebagai Penyebab Konflik: Kajian atas Teori Sosial Kontemporer. TEMALI: Jurnal Pembangunan Sosial, 2(1), 157-183. 